\title{
Pengaruh Model Pembelajaran Think Pair Share Berbasis Multimedia terhadap Kompetensi Pengetahuan IPS
}

\author{
Kd Rna Rahayu Putri ${ }^{1 *}$, IB. Gede Surya Abadi², I Km Ngurah Wiyasa ${ }^{3}$
}

123Jurusan Pendidikan Guru Sekolah Dasar, FIP, Universitas Pendidikan Ganesha Singaraja, Indonesia

\author{
A R T I C LEINFO \\ Article history: \\ Received 18 February \\ 2019 \\ Received in revised form \\ 20 March 2019 \\ Accepted 20 April 2019 \\ Available online 20 May \\ 2019 \\ Kata Kunci: \\ Think Pair Share, \\ Multimedia, Kompetensi \\ Pengetahuan IPS \\ Keywords: \\ Think Pair Share, \\ Multimedia, Social Science \\ Competence
}

\begin{abstract}
A B S T R A K
Penelitian ini bertujuan untuk mengetahui pengaruh model pembelajaran kooperatif tipe think pair share berbasis multimedia terhadap kompetensi pengetahuan IPS siswa kelas IV SD Gugus Letda Made Putra Kecamatan Denpasar Utara tahun pelajaran 2017/2018. Penelitian ini merupakan penelitian eksperimen semu (quasi eksperiment) dengan rancangan penelitian non-equivalent. Jumlah populasi adalah 393 siswa. Sampel ditentukan dengan menggunakan teknik sampel kelompok, yakni dengan mengacak kelas. Sampel yang terpilih dalam penelitian ini adalah kelas IV ${ }^{\mathrm{C}}$ SD Negeri 2 Dangin Puri sebagai kelompok eksperimen dengan jumlah 33 orang dan kelas IV SD Negeri 5 Tonja dengan jumlah 41 orang sebagai kelompok kontrol. Instrumen yang digunakan dalam mengumpulkan data penelitian berupa tes objektif yang telah divalidasi sebanyak 36 butir soal. Hasil analisis tersebut menunjukkan adanya perbedaan yang signifikan kompetensi pengetahuan IPS antara kelompok eksperimen dengan kelompok kontrol. Hal tersebut dibuktikan dengan hasil uji-t bahwa thitung $=6,193>t_{\text {tabel }}=2,000$ dengan kriteria taraf signifikansi $5 \%$ dan $\mathrm{dk}=72$. Demikian pula nilai rerata kompetensi pengetahuan IPS kelompok eksperimen $\bar{x}=0,59>\bar{x}=0,41$ rerata kompetensi pengetahuan IPS kelompok kontrol. Maka dapat dinyatakan bahwa model pembelajaran kooperatif tipe think pair share berbasis multimedia berpengaruh terhadap kompetensi pengetahuan IPS siswa kelas IV SD Gugus Letda Made Putra Kecamatan Denpasar Utara tahun pelajaran 2017/2018.
\end{abstract}

\section{A B S T R A C T}

This study aims to determine the effect of the cooperative learning model multimedia-based think pair share type on the IPS knowledge competency of the fourth-grade students of SD Gugus Letda Made Putra, North Denpasar District 2017/2018 academic year. This research is a quasiexperimental study with a non-equivalent research design. The total population is 393 students. The sample is determined using group sampling techniques, namely by randomizing the class. The sample chosen in this study was class IVc of Dangin Puri 2 Elementary School as an experimental group with a total of 33 people and class IVb SD Negeri 5 Tonja with a total of 41 people as a control group. The instruments used in collecting research data were 36 validated objective tests. The results of the analysis showed a significant difference between the IPS knowledge competencies between the experimental group and the control group. This is evidenced by the results of the t-test that $\mathrm{t}$ count = $6.193>\mathrm{t}$ table $=2,000$ with the criteria of the significance level was $5 \%$ and $\mathrm{dk}=72$. Likewise the mean score of the experimental group's IPS competency knowledge $\bar{x}=0.59>\mathrm{x} 41=0.41$, the average knowledge competency of the IPS control group. Then it can be stated that the cooperative learning model of multimedia-based think pair share influences the IPS knowledge competency of fourth-grade students of Elementary School, Letda Made Putra, North Denpasar District, 2017/2018 academic year.

\footnotetext{
${ }^{1}$ Corresponding author.

E-mail addresses: rnarahayuputri3@gmail.com (Kd Rna Rahayu Putri)
} 


\section{Pendahuluan}

Pendidikan dapat mencetak sumber daya manusia (SDM) yang berkualitas sebagai generasi penerus bangsa. Hal ini dikarenakan pendidikan sebagai kegiatan yang terpusat pada pembangunan sumber daya manusia mampu mengangkat harkat, derajat, dan martabat bangsa. Maju atau tidaknya suatu Negara dipengaruhi oleh faktor pendidikan, sebab pendidikan merupakan faktor terpenting dalam tatanan kehidupan suatu bangsa dan Negara. Pendidikan harus mampu menciptakan bangsa yang dapat diperhitungkan di era global seperti sekarang.

Kesuksesan suatu pendidikan tentu tidak bisa terlepas dari kurikulum pendidikan. Kurikulum dijadikan sebuah wadah yang akan menentukan arah pendidikan dan menjadi ujung tombak bagi terlaksananya kegiatan pendidikan. Kurikulum 2013 merupakan kurikulum yang baru mulai diterapkan di Indonesia pada tahun pelajaran 2013/2014. Kurikulum ini adalah pengembangan dari kurikulum sebelumnya, yakni Kurikulum Tingkat Satuan Pendidikan (KTSP). Pembelajaran pada Kurikulum 2013 terlaksana secara tematik dengan menggunakan pendekatan saintific.

IPS merupakan salah satu mata pelajaran pokok dalam struktur kurikulum 2013 pada jenjang sekolah dasar (SD). Wahidmurni (2017:17) mendifinisikan pengertian IPS, yakni suatu mata pelajaran yang bersumber dari kehidupan sosial masyarakat yang diseleksi dengan menggunakan konsep-konsep ilmu sosial".Pembelajaran IPS di sekolah dasar didesain berdasarkan fenomena faktual dan konseptual, sehingga dapat mengaitkan berbagai fakta, gagasan, dan peristiwa dari materi yang dipelajari. Gunawan (2011:56) menyatakan "pelaksanaan pembelajaran IPS di SD harus memperhatikan kebutuhan anak berusia 6-12 tahun yang berada pada tahap operasional konkret". Materi IPS berkenaan dengan kenyataan gejala dan masalah dalam kehidupan masyarakat.Inovasi dalam pembelajaran yang relevan terhadap kehidupan nyata siswa sehari-hari sangat diperlukandengan melibatkan siswa secara aktif dan kreatif dalam proses pembelajaran. Pada dasarnya dalam mata pelajaran IPS juga diperlukan ketekunan dalam membaca, sebab IPS mencakup informasi yang sangat luas. Menurut Aliputri (2018) dalam mengajarkan mata pelajaran IPS guru harus menguasai materi maupun keterampilan-keterampilan dalam mengajar, guru harus mampu memilih metode pembelajaran yang tepat dalam mengajarkan mata pelajaran IPS. Guru atau calon guru harus mampu mengubah metode ceramah yang biasa mereka gunakan dengan metode-metode pembelajaran baru yang lebih kreatif dan inovatif sehingga mampu menumbuhkan partisipasi siswa dalam mengikuti pembelajaran di kelas maupun luar kelas sehingga hasil belajar mereka dapat meningkat

Kurangnya antusias siswa dalam mengikuti proses pembelajaran dan kurangnya minat siswa dalam membaca materi pelajaran menjadi permasalahan yang ditemui dalam proses pembelajaran di SD Gugus Letda Made Putra Kecamatan Denpasar Utara. Padahal pada dasarnya mata pelajaran IPS memerlukan ketekunan dalam membaca untuk dapat mengaitkan berbagai konsep dan gagasan materi IPS terhadap kehidupan nyata dimasyarakat.

Berkaitan dengan hal tersebut diperlukan inovasi dalam merancang kegiatan pembelajaran secara kreatif, inovatif, menyenangkan, dan menantang dengan memperhatikan karakteristik perkembangan siswa sekolah dasar.Model pembelajaran yang kurang bervariasi tentunya dapat menimbulkan suasana yang tidak nyaman dan membosankan.Hal tersebut ditambah juga dengan kurangnya rasa kepercayaan diri siswa dalam mengemukakan pendapat di depan kelas karena takut akan kesalahan yang terjadi. Hal ini akan berdampak pada pencapaian kompetensi pengetahuan siswa yang belum mencapai kompetensi yang telah ditetapkan. Pencapaian kompetensi pengetahuan dipengaruhi oleh dua faktor yakni faktor internal yang berasal dari diri siswa dan faktor eksternal yang dapat berasal dari guru. Guru merupakan komponen yang sangat berperan dalam menciptakan suasana belajar yang dapat mempengaruhi pencapaian kompetensi siswa. Pembelajaran yang inovatif sangat dibutuhkan guru dalam membangun aktivitas belajar yang menyenangkan dan dapat memotivasi siswa agar lebih mudah memahami materi pelajaran, sehingga kompetensi yang telah ditetapkan dapat tercapai.Pada dasarnya dalam proses pembelajaran dapat digunakan berbagai model yang bervariasi dan memanfaatkan berbagai media untuk dapat mengemas pembelajaran menjadi lebih menarik, sehingga siswa akan lebih aktif dan semangat dalam belajar untuk dapat mencapai kompetensi yang telah ditetapkan.

Salah satu inovasi yang dapat dilakukan untuk pembaharuan pembelajaran di SD Gugus Letda Made Putra, yaitu dengan menerapkan sebuah model pembelajaran yang dapat melibatkan siswa secara aktif, sehingga dapat meningkatkan kualitas pembelajaran sesuai dengan harapan yang telah ditetapkan. Berbagai macam model pembelajaran dapat diterapkan untuk mengoptimalkan proses pembelajaran, salah satunya adalah model pembelajaran kooperatif tipe Think Pair Share (TPS).

Menurut Sulaiman (2014) Cooperative learning adalah pembelajaran yang secara sadar dan sengaja mengembangkan interaksi yang saling asuh antara siswa untuk menghindari ketersinggungan dan kesalahpahaman yang dapat menimbulkan permusuhan. Model pembelajaran ini akan mebekali 
kemandirian, kreatif serta keterlibatan lasing siswa dalam proses pembelajaran. Pendekatan ini merupakan konsekuensi logis dari penerapan paradigm baru dalam pendidikan yang antara lain, bahwa pendidikan di masa sekarang, bukanlah lagi dilihat semat-mata "mengisi air ke dalam gelas" atau sekedar mengisi otak anak dengan berbagai teori atau konsep ilmu pengetahuan, melainkan pengajaran yang lebih bersifat "menyalakan cahaya", yaitu mendorong, menggerakkan, dan membimbing peserat didik agar dapat mengembangkan imaginasi dan inspirasinya secara actual. Model pembelajaran dengan paradigma baru ini menempatkan guru bukan sebagai orang serba tahu yang dengan otoritas yang dimilikinya dapat menuangkan berbagai ide dan gagasan, melainkan hanya sebagai salah satu sumber informasi, penggerak, pendorong dan pembimbing agar peserta didik dengan kemauannya mengarah pada terjadinya masyarakat belajar (learning society). Taniredja (2012:55) menyatakan "pembelajaran kooperatif merupakan sistem pengajaran yang memberi kesempatan kepada siswa untuk bekerja sama dengan sesama siswa dalam tugas-tugas terstruktur". Model pembelajaran kooperatif menekankan adanya kerjasama yang dilakukan siswa dalam kelompok kecil untuk memecahkan suatu permasalahan guna mencapai tujuan pembelajaran yang telah ditetapkan. Menurut Syamsir (2016) guru hendaknya memilih dan menggunakan model pembelajaran yang banyak melibatkan siswa aktif dalam belajar. Salah satu model pembelajaran yang dapat membantu siswa untuk ikut aktif adalah model pembelajaran kooperatif tipe Think Pair Share (TPS). Menurut Fatimah (2015) metode Cooperative Learning tipe Think Pair Share adalah salah satu model pembelajaran kooperatif sederhana yang memberi kesempatan kepada setiap siswa untuk melakukan proses kegiatan "berpikir-berpasaangan-berbagi" dalam mengikuti pembelajaran. Menurut Sugiharti (2018) dalam penerapan model pembelajaran, guru harus memperhatikan dan menyesuaikan dengan kondisi kelas serta tujuan pembelajaran yang akan dicapai. Ada beberapa model pembelajaran, salah satunya adalah model pembelajaran kooperatif. Model pembelajaran kooperatif merupakan model pembelajaran yang diterapkan pada kelompok-kelompok kecil, dimana setiap anggota kelompok memiliki kemampuan yang berbeda-beda. Banyak sekali tipe pembelajaran kooperatif, salah satunya adalah Think Pair Share (TPS). "Think Pair Share merupakan salah satu model pembelajaran kooperatif yang dirancang untuk mempengaruhi pola interaksi siswa" (Kurniasih dan Sani, 2015:58). Pola interaksi tersebut dilakukan melalui tiga tahapan yaitu berpikir (think), berpasangan dengan kelompok kecil (pair), dan berbagi (share). Pembelajaran melalui model think pair share menekankan pada kemampuan siswa untuk berpikir secara individu terkait dengan pemahamannya terhadap materi pelajaran dan berdiskusi dengan kelompok kecil untuk memperluas wawasannya yang kemudian akan disampaikan atau dibagikan kepada kelompok yang lebih besar. Kegiatan ini melatih siswa untuk banyak berpikir dan berani berpendapat, serta menghargai pendapat orang lain. Asmani (2016:123) menyatakan "pembelajaran dengan model inimerupakan suatu cara yang efektif untuk membuat variasi suasana pola diskusi dalam proses pembelajaran”. Menurut Nurdin (2017) TPS digunakan untuk menciptakan interaksi yang dapat mendorong rasa ingin tahu, ingin mencoba, bersikap mandiri, dan ingin maju. Guru memberi informasi, hanya informasi yang mendasar saja, sebagai dasar pijakan bagi anak didik dalam mencari dan menemukan sendiri informasi lainnya. Atau guru menjelaskan materi dengan mengaitkannya dengan pengalaman dan pengetahuan anak sehingga memudahkan mereka menanggapi dan memahami pengalaman yang baru bahkan membuat anak didik mudah memusatkan perhatian. Karenanya guru sangat perlu memperhatikan pengalaman dan pengetahuan anak didik yang didapatinya dalam kehidupan sehari-hari.

Model pembelajaran kooperatif tipe think pair share akan lebih efektif dan bermakna jika dikombinasikan dengan media pembelajaran yang inovatif. Materi pelajaran akan lebih mudah dan jelas jika dalam penyampaiannya menggunakan media pembelajaran, sehingga pembelajaran akan menjadi lebih efektif dan efisien. Media pembelajaran merupakan alat bantu yang digunakan sebagai perantara dalam menyampaikan materi pelajaran (Musfiqon, 2014:26).Penggunaan media pembelajaran dapat menyalurkan pesan, merangsang pikiran, perasaan, perhatian, dan kemauan siswa sehingga dapat terdorong terlibat dalam proses pembelajaran. Media dapat dijadikan sebagai alat bantu yang digunakan dalam proses pembelajaran untuk menyampaikan materi pelajaran agar tercapainya tujuan pendidikan.

Penggunaan multimedia dapat dikombinasikan dengan model pembelajaran kooperatif tipe think pair share dalam membantu siswa mencapai kompetensi yang telah ditetapkan. Wati (2016:129) mengemukakan multimedia merupakan perpaduan berbagai macam media yang ditampilkan, baik dalam bentuk teks, grafik, gambar, foto, animasi, audio, maupun video yang digunakan sebagai sarana untuk menyampaikan informasi. Jumlah media yang digabungkan dalam suatu pembelajaran tentunya lebih dari satu media. Pembelajaran dengan menggunakan multimedia secara tepat dan baik akan memberikan manfaat yang besar bagi guru dalam penyampaian materi dan dapat membantu siswa dalam memahami materi pelajaran.Kosasih (2014:48) yang menyatakan bahwa "multimedia dapat melibatkan pengalaman siswa secara langsung dengan yang melibatkan semua indra".Kemampuan dan keterampilan guru menjadi kunci utama dalam pembelajaran berbasis multimedia. Pembelajaran menggunakan multimedia 
menuntut guru lebih menguasai teknologi, sebab multimedia lebih cenderung berupa hasil rekayasa teknologi terutama dalam bidang komputer.

Model pembelajaran kooperatif tipe think pair share berbasis multimedia merupakan suatu inovasi pembelajaran yang melatih siswa untuk aktif bekerja sendiri dan bekerjasama dalam kelompok yang dikombinasikan dengan multimedia pada suatu proses pembelajaran. Dikombinasikannya model pembelajaran kooperatif tipe think pair share dengan multimedia menjadikan suatu pembelajaran lebih bermakna dan siswa menjadi lebih aktif membangun pengetahuannya. Sehingga siswa menjadi lebih kreatif dan mampu meningkatkan kepercayaan dirinya dalam menyampaikan pemahamannya terkait dengan materi pelajaran karena telah memperoleh informasi tambahan dari siswa lainnya pada tahap diskusi dan berbagi.

Tujuan penelitian ini adalah untuk mengetahui pengaruh model pembelajaran kooperatif tipe think pair share berbasis multimedia terhadap kompetensi pengetahuan IPS siswa kelas IV SD Gugus Letda Made Putra Kecamatan Denpasar Utara.

\section{Metode}

Pelaksanaan penelitian dilaksanakan di SD Gugus Letda Made Putra Kecamatan Denpasar Utara selama satu bulan mulai maret hingga april. Perlakuan dengan pembelajaran menggunakan model kooperatif tipe think pair share berbasis multimedia pada kelompok eksperimen dilakukan sebanyak 6 kali pertemuan dalam proses pembelajaran dan 6 kali pertemuan juga dalam proses pembelajaran pada kelompok kontrol. Pelaksanaan perlakukan yang diberikan dalam proses pembelajaran telah disesuaikan dengan jam pelajaran terkait materi IPS.

Penelitian ini tergolong penelitian kuantitatif dengan rancangan eksperimen yaitu quasi eksperiment (eksperimen semu). Hal ini dikarenakan ketidakmampuan mengontrol secara ketat variabel lain di luar variabel perlakuan dalam kondisi eksperimen. Rancangan eksperimen yang digunakan dalam penelitian ini menggunakan dua kelompok kelas, yakni kelompok eksperimen dan kelompok kontrol. Satu kelas sebagai kelompok eksperimen mendapatkan perlakukan dengan menerapkan model pembelajaran kooperatif tipe think pair share berbasis multimedia dan satu kelas lainnya sebagai kelompok kontrol dengan pembelajaran secara konvensional. Bentuk rancangan eksperimen semu yang digunakan adalah Rancangan Kelompok Non-Ekuivalen. Populasi dari penelitian ini adalah seluruh siswa kelas IV SD Gugus Letda Made Putra Kecamatan Denpasar Utara tahun pelajaran 2017/2018 berjumlah 393 orang, yang terdiri dari 11 kelas dalam 6 SD. Pengambilan sampel dari populasi menggunakan teknik sampling.

Teknik sampling yang digunakan untuk pengambilan sampel pada penelitian ini adalah teknik sampel kelompok (rumpun). Pengambilan sampel tidak dilakukan dengan mengacak setiap individu dari setiap kelas, melainkan diambil dari kelompok atau kelas yang sudah terbentuk. Hal ini dikarenakan tidak bisa mengubah kelas yang telah terbentuk sebelumnya. Penentuan sampel akan dilakukan dengan cara pengundian, yakni seluruh kelas IV yang ada pada populasi akan diundi. Pengundian ini akan memberikan kesempatan bagi setiap kelompok atau kelas untuk memperoleh peluang yang sama menjadi sampel penelitian.Teknik undi dalam menentukan sampel dilakukan sebanyak 2 kali pengundian. Pengundian pertama dilakukan untuk menentukan dua kelompok yang akan dijadikan sebagai sampel. Kedua kelompok diberikan pretest untuk menyetarakan secara akademik. Kedua kelompok yang dinyatakan setara akan dilakukan pengundian kembali bagi kedua kelompok tersebut untuk menentukan kelas yang akan dijadikan kelompok eksperimen dan kelompok kontrol. Dari hasil pengundian yang dilakukan diperoleh kelompok sampel yaitu kelas IVc SD Negeri 2 Dangin Puri sebagai kelompok eksperimen dan kelas IVb SD Negeri 5 Tonja senagai kelompok kontrol.

Penelitian ini dilaksanakan melalui tiga tahapan, yaitu tahap persiapan, tahap pelaksanaan, dan tahap akhir eksperimen. Pada tahap persiapan dilakukan diskusi dengan guru terkait pelaksanaan pembelajaran yang akan dilakukan. Hal ini bertujuan agar dapat memahami terlebih dahulu prinsip dasar dan prosedur dari penelitian dengan menggunakan model pembelajaran kooperatif tipe think pair share berbasis multimedia. Berbagai persiapan juga dilakukan pada tahap awal ini, seperti melakukan wawancara dengan wali kelas yang diteliti, menyusun RPP berkaitan dengan penelitian yang dilakukan, mendiskusikan RPP yang digunakan dalam proses pembelajaran bersama wali kelas dan dosen pembimbing, menyiapkan perangkat pendukung pembelajaran yang akan digunakan, menyiapkan kelas yang akan digunakan sebagai kelas eksperimen dan kontrol, dan mendiskusikan intrumen penelitian yang digunakan bersama dengan wali kelas dan dosen pembimbing. Tahap pelaksanaan eksperimen mulai dilakukan dengan memberikan perlakukan pada kelompok eksperimen melalui model pembelajaran kooperatif tipe think pair share berbasis multimedia. Perlakuan diberikan sebanyak 6 kali yang telah disesuaikan dengan jam pelajaran terkait muatan materi. Diakhir penelitian kedua kelompok diberikan posttest untuk dapatmenganalisis data hasil penelitian dari sampel. 
Data yang diperlukan untuk penelitian ini yakni data hasil kompetensi pengetahuan IPS siswa kelas IV SD Gugus Letda Made Putra Kecamatan Denpasar Utara. Data kompetensi pengetahuan tersebut diperoleh menggunakan metode tes. Pada umumnya metode tes digunakan untuk mengukur aspek kognitif siswa, oleh karena itu metode tes sangat tepat digunakan untuk mengukur kompetensi pengetahuan siswa. Data kompetensi pengetahuan IPS dikumpulkan melalui tes kompetensi pengetahuan IPS.

Tes yang digunakan untuk mengukur kompetensi pengetahuan siswa dalam penelitian ini berupa tes objektif dalam bentuk pilihan ganda biasa. Tes disusun berdasarkan indikator-indikator muatan materi IPS sesuai dengan tema. Penyusunan butir tes dilakukan setelah menyusun kisi-kisi (blue print) agar tes yang disusun tidak menyimpang dari materi pelajaran. Sebelum tes diberikan kepada kelompok sampel, terlebih dahulu dilakukan validasi instrumen, yakni dengan uji validitas, reliabilitas, daya beda, dan tingkat kesukaran. Berdasarkan hasil uji validasi instrumen dari 50 butir soal, diperoleh 36 butir soal yang layak digunakan untuk mengukur kompetensi pengetahuan IPS siswa.

Teknik analisis yang digunakan untuk menganalisis data dalam penelitian ini, yakni teknik analisis statistik inferensial. Statistik inferensial digunakan untuk menganalisis data gain skor yang dinormalisasi dari hasil pretest dan posttest. Analisis statistik inferensial bertujuan untuk menguji hipotesis penelitian yang diajukan dan kesimpulan ditarik berdasarkan hasil pengujian terhadap hipotesis.Dalam hal ini teknik analisis data yang digunakan untuk uji hipotesis menggunakan uji-t. Sebelum uji-t dilakukan, terlebih dahulu harus memenuhi uji prasyarat analisis, yaitu dengan uji normalitas sebaran data dan uji homogenitas varians. Dalam penelitian ini uji normalitas sebaran data dihitung menggunakan Kolmogorov-Smirnov dengan kriteria pengujian pada taraf signifikansi 5\%, jika harga nilai maksimum | Ft - Fs | < harga nilai tabel Kolmogorov-Smirnov, maka $\mathrm{H}_{0}$ diterima dan data berdistribusi normal. Uji homogenitas varians dihitung menggunakan rumus uji $\mathrm{F}$ dengan kriteria pengujian dilakukan pada taraf signifikansi $5 \%$ melalui derajat kebebasan untuk pembilang $\mathrm{n}_{1}-1$ dan derajat kebebasan untuk penyebut $\mathrm{n} 2-1$, jika $\mathrm{F}_{\text {hitung }} \leq \mathrm{F}_{\text {tabel, }}$, maka sampel dinyatakan homogen.

Pengujian hipotesis terhadap hipotesis observasi $\left(\mathrm{H}_{0}\right)$ dihitung menggunakan uji-t dengan rumus polled varians.Kriteria pengujian pada taraf signifikansi $5 \%$ dan derajat kebebasan $(\mathrm{dk})=\mathrm{n}_{1}+\mathrm{n}_{2}-2$, jika $t_{\text {hitung }} \leq t_{\text {tabel}}$, maka $H_{o}$ diterima dan Ha ditolak. Sebaliknya jika $t_{\text {hitung }}>t_{\text {tabel }}$, maka $H_{o}$ ditolak dan $\mathrm{Ha}$ diterima.

\section{Hasil dan Pembahasan}

Hasil penelitian ini disajikan dalam bentuk deskripsi data kompetensi pengetahuan IPS tema daerah tempat tinggalku pada siswa kelas IV SD Gugus Letda Made Putra Kecamatan Denpasar Utara Tahun Pelajaran 2017/2018. Data kompetensi pengetahuan IPS siswa kelompok eksperimen dan kontrol diperoleh setelah melaksanakan pembelajaran dengan menganalisis hasil pretest dan posttest untuk memperoleh data gain skor ternormalisasi. Data yang diperoleh dalam penelitian ini dikelompokkan menjadi 2, yakni: (a) data kompetensi pengetahuan IPS kelompok eksperimen, (b) data kompetensi pengetahuan IPS kelompok kontrol.

Deskripsi perolehan data pada kelompok eksperimen menunjukkan nilai maksimum gain skor ternormalisasi kompetensi pengetahuan IPS terhadap 33 orang siswa adalah 0,89 dengan nilai minimum 0,40 . Data tersebut kemudian dianalisis untuk mengetahui rata-rata (mean) gain skor ternormalisasi kompetensi pengetahuan IPS siswa kelompok eksperimen yakni 0,59 dan standar deviasi $(0,13)$, serta varians (0,016).Distribusi frekeuensi data gain skor ternormalisasi kompetensi pengetahuan IPS kelompok eksperimen dapat digambarkan dengan histogram yang tampak pada gambar 1.

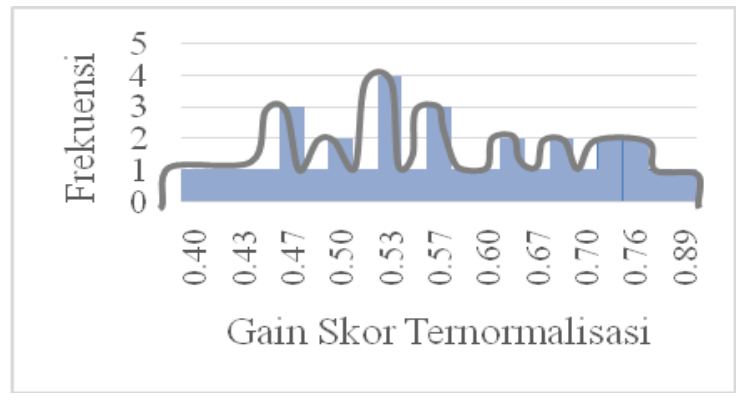

Gambar 1. Grafik Histrogram Distribusi Frekuensi Gain Skor Kelompok Eksperimen 
Deskripsi perolehan data pada kelompok kontrol terhadap 41 orang siswa menunjukkan nilai maksimum gain skor ternormalisasi kompetensi pengetahuan IPS siswa yakni 0,74 dengan nilai minimum 0,16. Perolehan rata-rata (mean) gain skor ternormalisasi kompetensi pengetahuan IPS siswa kelompok eksperimen yakni 0,41 dan standar deviasi $(0,12)$, serta varians $(0,015)$. Distribusi frekeuensi data gain skor ternormalisasi kompetensi pengetahuan IPS kelompok kontrol dapat digambarkan dengan histogram yang tampak pada gambar 2 .

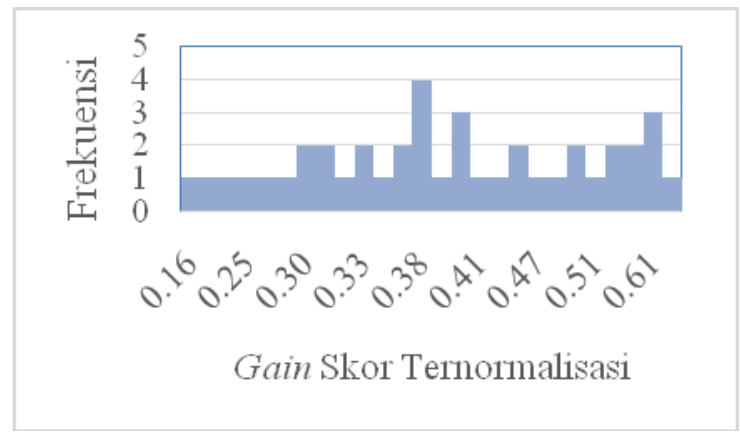

Gambar 2. Grafik Histrogram Distribusi Frekuensi Gain Skor Kelompok Kontrol

Hasil analisis data tersebut menunjukkan kompetensi pengetahuan IPS siswa yang dibelajarkan melalui model pembelajaran kooperatif tipe think pair share berbasis multimedia memiliki rata-rata gain skor ternormalisasi yang lebih tinggi dari kelompok siswa yangdibelajarkan secara konvensioanal, yakni $\overline{\mathrm{x}}=0,59>\overline{\mathrm{x}}=0,41$.

Hal tersebut terjadi karena adanya pengaruh dari beberapa faktor. Pertama, pembelajaran dengan model kooperatif tipe think pair share berbasis multimedia yang efektif dan efisien dapat membuat pembelajaran IPS lebih bermakna karena siswa dituntut untuk menggali informasi agar dapat menjawab pertanyaan yang diberikan guru. Kebermaknaan tersebut berpengaruh positif terhadap pencapain kompetensi pengetahuan IPS siwa. Kedua, pembelajaran dengan model kooperatif tipe think pair shareberbasis multimedia, dapat melatih siswa berpikir kritis dan kreatif, karena diberikan kesempatan untuk berpikir secara individu sebelum dilakukan tahap diskusi. Ketiga, model pembelajaran kooperatif tipe think pair share berbasis multimedia dapat melatih siswa untuk memiliki tanggung jawab lebih dalam menjawab pertanyaan yang diajukan.

Sebelum data penelitian ini dianalisis dengan statistik inferensial menggunakan uji-t, terlebih dahulu dilakukan uji prasayarat analisis terhadap data-data hasil penelitian. Uji prasyarat analisis dilakukan untuk memperoleh fakta tentang normalitas sebaran data dan homogenitas data varians antar kedua kelompok. Prasyarat yang harus dipenuhi adalah sebaran data berdistribusi normal dan varians antar kelompok homogen.

Uji normalitas digunakan untuk mengetahui apakah sebaran data nilai kompetensi pengetahuan IPS siswa masing-masing kelompok kelas berdistribusi normal atau tidak, sehingga dapat menentukan teknik analisis datanya. Uji normalitas dihitung dengan rumus Kolmogorov-Smirnov. Berdasarkan hasil uji normalitas sebaran data kelompok eksperimen, diperoleh harga nilai maksimum | Ft - Fs | sebagai angka penguji normalitas, yaitu 0,135< harga tabel Kolmogorov-Smirnov = 0,231 maka $\mathrm{H}_{\mathrm{o}}$ diterima dan sebaran data gain skor ternormalisasi kompetensi pengetahuan IPS kelompok eksperimen berditribusi normal. Sedangkan hasil uji normalitas sebaran data kelompok kontrol, diperoleh harga nilai maksimum | Ft - Fs | sebagai angka penguji normalitas, yaitu 0,105 < harga tabel Kolmogorov-Smirnov = 0,212 maka $\mathrm{H}_{0}$ diterima dan sebaran data gain skor ternormalisasi kompetensi pengetahuan IPS kelompok kontrol berdistribusi normal.

Setelah data gain skor ternormalisasi kelompok eksperimen dan kontrol dinyatakan berdistribusi normal, maka dilanjutkan dengan pengujian homogenitas varians antar kelompok. Berdasarkan hasil analisis diperoleh $F_{\text {hitung }}=1,07$ dan $F_{\text {tabel }}=1,76$ pada taraf signifikansi $5 \%$ dan dk $=40,32$. Sehingga $F_{\text {hitung }}<$ $\mathrm{F}_{\text {tabel }}$ yang berarti data nilai gain skor ternormalisasi kedua kelompok dinyatakan homogen.

Berdasarkan hasil uji prasyarat analisis data, diperoleh bahwa data nilai gain skor ternormalisasi kelompok eksperimen dan kontrol berdistribusi normal dan homogen. Setelah diperoleh hasil dari uji prasyarat analisis data, maka dilanjutkan dengan menguji hipotesis penelitian dengan menggunakan uji-t, yakni polled varians.Berdasarkan hasil uji hipotesis yang telah dilakukan dengan menganalisis data gain skor ternormalisasi, diperoleh hasil yang disajikan dalam tabel sebagai berikut. 
Tabel 01. Rekapitulasi Hasil Analisis Uji Hipotesis

\begin{tabular}{lcccccc}
\hline Kelompok & $\begin{array}{c}\text { Rerata gain skor } \\
\text { ternormalisasi }\end{array}$ & $\boldsymbol{S}^{\mathbf{2}}$ & $\mathbf{N}$ & $\mathbf{D k}$ & $\mathbf{t}_{\text {hitung }}$ & $\mathbf{t}_{\text {tabel }}$ \\
\hline Eksperimen & 0,59 & 0,016 & 33 & 72 & 6,193 & 1,993 \\
Kontrol & 0,41 & 0,015 & 41 & & & \\
\hline
\end{tabular}

Berdasarkan hasil analisis data diperoleh $t_{\text {hitung }}=6,193$. Dengan menggunakan taraf signifikansi $5 \%$ dan $\mathrm{dk}=72$ maka diperoleh batas penolakan $\mathrm{H}_{\mathrm{o}}$ sebesar 1,993. Berdasarkan kriteria pengujian $\mathrm{t}_{\text {hitung }}>$ $t_{\text {tabel }}\left(t_{\text {hitung }} 6,193>t_{\text {tabel }} 1,993\right)$, maka $H_{o}$ yang diajukan ditolak dan $H_{a}$ diterima yang berarti terdapat perbedaan yang signifikan kompetensi pengetahuan IPS antara kelompok siswa yang dibelajarkan melalui model pembelajaran kooperatif tipe think pair share berbasis multimedia dengan kelompok siswa yang dibelajarkan secara konvensional pada kelas IV SD Gugus Letda Made Putra Kecamatan Denpasar Utara tahun pelajaran 2017/2018.

Perbedaan perlakuan yang diberikan pada proses pembelajaran berpengaruh terhadap kompetensi pengetahuan IPS siswa. Hal ini terlihat dari rata-rata nilai gain skor ternormalisasi kompetensi pengetahuan IPS siswa kelompok eksperimen lebih tinggi dari rata-rata nilai kelompok kontrol ( $\overline{\mathrm{x}}$ ekperimen $=0,59>\overline{\mathrm{x}}$ kontrol $=0,41$ ). Pada awalnya diketahui kedua kelompok memiliki kemampuan yang setara, hal ini terlihat dari hasil uji kesetaraan dengan menganalisis data pretest. Setelah diberikan perlakuan pada kelompok eksperimen, yakni dengan menerapkan model pembelajaran kooperatif tipe think pair share berbasis multimedia perolehan nilai kompetensi pengetahuan IPS menunjukkan perbedaan. Kompetensi pengetahuan IPS siswa kelompok eksperimen lebih baik jika dibandingkan dengan kompetensi pengetahuan IPS siswa pada kelompok kontrol.

Proses pembelajaran pada kelompok eksperimen yang menerapkan model pembelajaran kooperatif tipe think pair share berbasis multimedia berlangsung dengan optimal dan kondusif. Hal ini dikarenakan model pembelajaran kooperatif tipe think pair share berbasis multimedia mendorong siswa untuk aktif menggali pengetahuannya sendiri, merasa senang sehingga antusias dalam mengikuti proses pembelajaran, dan dapat memudahkan siswa dalam memahami materi pelajaran dengan digunakannya berbagai jenis media yang ditampilkan melalui LCD. "Model pembelajaran kooperatif tipe think pair share memperkenalkan gagasan tentang waktu 'tunggu atau berpikir' (wait or think time) pada elemen interaksi pembelajaran yang dapat menjadi salah satu faktor ampuh dalam meningkatkan respons siswa terhadap pertanyaan" (Huda, 2016:206). Langkah-langkah model pembelajaran kooperatif tipe think pair share menjadikan siswa lebih aktif dan kreatif dalam menggali informasi terkait dengan materi pelajaran, menjawab pertanyaan yang diajukan, serta melatih keterampilan berbicara siswa dalam menyampaikan pemahamanna terkait dengan materi pelajaran.

Model pembelajaran kooperatif tipe think pair share dikombinasikan dengan multimedia dalam kegiatan pembelajaran sebagai perantara dalam penyampaian materi pelajaran. Musfiqon (2014:187) menyatakan "pembelajaran berbasis multimedia memiliki karakteristik lebih sesuai dengan konteks materi yang dipelajari". Pembelajaran menjadi realistis dan kontekstual dengan menstimulus siswa untuk memahami dan mengaitkan konsep serta gagasan terhadap kehidupan nyata dimasyarakat.

Pembelajaran melalui model kooperatif tipe think pair share berbasis multimedia menekankan pada keaktifan siswa dalam proses berpikir secara individu mengenai permasalahan yang diberikan. Setelah kegiatan berpikir secara individu, siswa akan berdiskusi dengan kelompok untuk memperoleh kesepakatan bersama terkait dengan pemikiran yang disampaikan oleh teman kelompoknya. Proses pembelajaran dengan model kooperatif tipe think pair share berbasis multimedia dikemas dengan memperhatikan keaktifan siswa dalam kemampuan berpikir secara individu dan saling bertukar pendapat bersama kelompoknya dengan penggunaan multimedia didalamnya. Setiap siswa berkesempatan lebih luas untuk mengkonstruksikan pengetahuannya melalui kegiatan yang bermakna dalam proses berpikir dan berdiskusi.

Hasil penelitian ini memperkuat penelitian yang relevan oleh Ariantini (2017) yang menyatakan bahwa terdapat perbedaan yang signifikan pada hasil belajar antara kelompok siswa yang mengikuti pembelajaran dengan menggunakan model think pair share dengan kelompok siswa yang mengikuti pembelajaran secara konvensioanl dan Jasdilla (2017) yang menyimpulkan model pembelajaran kooperatif tipe think pair share dapat meningkatkan hasil belajar IPS siswa. Selain itu juga penelitian oleh Hermawan (2014) yang menyatakan dan Antari (2013) yang menyimpulkan terdapat perbedaan kompetensi pengetahuan siswa yang mengikuti pembelajaran berbasis multimedia dengan siswa yang mengikuti pembelajaran tidak berbasis multimedia.

Berdasarkan uraian tersebut, maka model pembelajaran kooperatif tipe think pair share berbasis multimedia dapat dikatakan mampu memberikan pengaruh yang baik terhadap penguasaan kompetensi 
pengetahuan IPS siswa. Hal ini terbukti dengan perbandingan rata-rata kompetensi pengetahuan IPS siswa kelompok eksperimen lebih tinggi dari rata-rata kompetensi pengetahuan IPS siswa kelompok kontrol.

\section{Simpulan dan Saran}

Berdasarkan hasil penelitian dan pembahasan dapat disimpulkan bahwa model pembelajaran kooperatif tipe think pair share berbasis multimedia berpengaruh terhadap kompetensi pengetahuan IPS siswa kelas IV SD Gugus Letda Made Putra Kecamatan Denpasar Utara tahun pelajaran 2017/2018. Hal ini dibuktikan dengan hasil analisis uji-t data gain skor ternormalisasi dengan perolehan $t_{\text {hitung }}=6,193$ dan $t_{\text {tabel }}$ dengan taraf signifikansi $5 \%$ dan $d k=72$ diperoleh $t_{\text {tabel }}=1,993$. Sehingga $t_{\text {hitung }}=6,193>t_{\text {tabel }}=$ 1,993. Hasil analisis yang diperoleh, harga $t_{\text {hitung }}>$ harga $t_{\text {tabel }}$ maka $\mathrm{H}_{\mathrm{o}}$ ditolak dan $\mathrm{H}_{a}$ diterima. Hal ini berarti terdapat perbedaan yang signifikan kompetensi pengetahuan IPS kelompok eksperimen dan kelompok kontrol pada siswa kelas IV SD Gugus Letda Made Putra Kecamatan Denpasar Utara tahun pelajaran 2017/2018. Rata-rata kompetensi pengetahuan IPS siswa kelompok eksperimen $\bar{x}=0,59>\bar{x}=$ 0,41 rata-rata kompetensi pengetahuan IPS siswa kelompok kontrol. Berdasarkan perbedaan tersebut model pembelajaran kooperatif tipe think pair share berbasis multimedia berpengaruh terhadap kompetensi pengetahuan IPS siswa kelas IV SD Gugus Letda Made Putra Kecamatan Denpasar Utara.

Berdasarkan penelitian yang telah dilakukan, maka dapat disampaikan beberapa saran yakni, 1) Hasil penelitian menunjukkan bahwa terdapat pengaruh model pembelajaran kooperatif tipe think pair share berbasis multimedia terhadap kompetensi pengetahuan IPS siswa, untuk itu guru dapat menjadikan model pembelajaran kooperatif tipe think pair share berbasis multimedia sebagai alternatif dalam mengkreasikan pembelajaran. 2) Materi pelajaran yang digunakan dalam penelitian ini terbatas pada muatan pelajaran IPS dengan tema daerah tempat tinggalku, sehingga untuk mengetahui kemungkinan hasil yang berbeda pada pokok bahasan lainnya, disarankan kepada peneliti selanjutnya untuk melakukan penelitian yang sejenis pada pokok bahasan lainnya. 3) Disadari adanya keterbatasan pada pokok bahasan yang telah ditetapkan dan keterbatasan waktu yang disediakan kepada pihak sekolah, perlakuan yang diberikan kepada siswa sangatlah singkat jika digunakan untuk mengetahui pengaruh model pembelajaran kooperatif tipe think pair shareberbasis multimedia terhadap kompetensi pengetahuan siswa, untuk itu disarankan agar memperoleh gambaran yang lebih meyakinkan hendaknya peneliti lain melakukan penelitian dalam jangka waktu yang lebih lama.

\section{Daftar Rujukan}

Aliputri, Dhestha Hazilla. 2018. Penerapan Model Pembelajaran Kooperatif Tipe Make A Match Berbantuan Kartu Bergambar untuk Meningkatkan Hasil Belajar Siswa. Jurnal Bidang Pendidikan Dasar (JBPD), Vol.2 No. 1A Hal. 70-77. http: ejournal.unikama.ac.id/index.php/JBPD. Diakses 4 Juni 2019.

Antari,Wina. 2013. "Pengaruh Model kooperatif tipe think pair share(Berbantuan Multimedia terhadap Hasil Belajar IPS Siswa Kelas V SD Gugus I Denpasar Selatan". Jurusan Pendidikan Guru Sekolah Dasar FIP Undiksha, Volume 1, Nomor 1 (hlm 1).

Ariantini Afri, Ni Kadek. 2017. "Pengaruh Model Pembelajaran Think Pair Shareterhadap Hasil Belajar IPA Siswa Kelas V SD Gugus II Kecamatan Melaya”. E-journal. Jurusan Pendidikan Guru Sekolah Dasar FIP Undiksha, Volume Nomor 2 (hlm 1).

Asmani, Ma'mur. 2016. Tips Efektif Cooperative Learning. Yogyakarta: Diva Press.

Ega Rima. 2016. Ragam Media Pembelajaran Visual - Audio Visual -Komputer-Power Point-InternetInteractive Video. Yogyakarta: Kata Pena.

Fatimah, Nuraini. 2015. Implementasi Cooperative Learning Tipe Think-Pair-Share dalam Pembelajaran Bercerita di Sekolah Menengah Pertama. Jurnal Penelitian Humaniora, Vol. 16, No. 2 Hal. 90-98. http://journals.ums.ac.id/index.php/humaniora/article/view/1862. Diakses 4 Juni 2019.

Gunawan, Rudy. 2011. Pendidikan IPS "Filosofi, Konsep, dan Aplikasi". Bandung: Alfabeta.

Huda, Miftahul. 2016. Model-model Pengajaran dan Pembelajaran. Yogyakarta: Pustaka Pelajar. 
Jasdilla. 2017. "Hasil Belajar dan Pembelajaran Kooperatif Tipe Think Pair Share". Jurusan Pendidikan Dasar Universitas Pendidikan Indonesia. Volume 6, Nomor 1 (hlm. 96).

Kosasih, E. 2014. Strategi Belajar dan Pembelajaran Implementasi Kurikulum 2013. Bandung: Yrama Widya.

Kurniasih, Imas dan Berlin Sani. 2015. Ragam Pengembangan Model Pembelajaran untuk Peningkatan Profesionalitas Guru. Yogyakarta: Kata Pena.

Musfiqon, 2012. Pengembangan Media dan Sumber Pembelajaran. Jakarta: PT. Prestasi Pustakarya.

Nurdin, Elan Artono, Bejo Apriyanto, Fahrudi Ahwan Ikhsan, dan Fahmi Arif Kurnianto. 2017. Pengaruh Model Pembelajaran Think Pair And Share Ditinjau dari Kemandirian Belajar terhadap Hasil Belajar IPS Siswa. Jurnal Pendidikan Ekonomi: Jurnal Ilmiah Ilmu Pendidikan, Ilmu Ekonomi, dan Ilmu Sosial Volume 11 Nomor 2 Hal. https://jurnal.unej.ac.id/index.php/JPE/article/download/5729/4264/. Diakses 4 Juni 2019.

Sugiharti, Eka Handayani. 2018. Efektivitas Think Pair Share terhadap Hasil Belajar Matematika Ditinjau dari Kemampuan Awal. Prosiding Seminar Nasional Etnomatnesia Hal. 505-510. http://jurnal.ustjogja.ac.id/index.php/etnomatnesia/article/view/2374. Diakses 4 Juni 2019.

Sulaiman. 2014. Model Pembelajaran Cooperative Learning (Suatu Analisis Psikologis dalam Pembelajaran). Vol. V No. 2 Hal. 25-35. https://repository.ar-raniry.ac.id/2003/1/. Diakses 4 Juni 2019.

Syamsir Kamal. 2016. Implementasi Model Pembelajaran Think-Pair-Share (TPS) untuk Meningkatkan Aktivitas dan Hasil Belajar Siswa Kelas XII SMA Negeri 10 Banjarmasin Tahun Pelajaran 2015/2016 pada Materi Barisan dan Deret. Jurnal Pendidikan Matematika Vol. 2, No. 1 Hal. 1-11. https://media.neliti.com/media/publications/176897-ID-implementasi-model-pembelajaranthink-pa.pdf. Diakses 4 Juni 2019.

Wahidmurni. 2017. Metodologi Pembelajaran IPS: Pengembangan Standar Proses Pembelajaran IPS di Sekolah/Madrasah. Yogyakarta: Ar-Ruzz Media. 